\title{
A Textual Criticism and Lexical Analysis of Isaiah 62
}

\author{
Philip Suciadi Chia' ${ }^{1)}$, Juanda ${ }^{2}$ \\ 1) Southern Baptist Theological Seminary - Kentucky USA \\ E-mail:pchia275@students.sbts.edu \\ 2) Evangelical Theological Seminary of Indonesia - Surabaya \\ E-mail: juanda@sttii-surabaya.ac.id
}

\begin{abstract}
This research presents a methodology and example of doing both a textual criticism and a word study or a lexical analysis of the Hebrew word. The textual external evidence strongly favors the consonantal text of reading one because all the ancient versions support it. The internal evidence, though it is not as strong as external evidence, has endorsements from its context and appearances of that word in Hebrew Bible. In Isaiah 62:1, the best understanding of לִ is not from literal sense but rather symbolic. The context of the usage of this term is God will restore Zion, particularly in her salvation, which is symbolized as a torch that burns. It means that Yahweh will make glorious Zion's deliverance like a torch so that all nations, including their kings, will be witnesses of Zion's restoration.
\end{abstract}

Keywords: Variants, Text, Evidence

\section{INTRODUCTION}

This research presents a methodology and example of doing both a textual criticism and a word study or a lexical analysis of the Hebrew word. These examples are taken from Isaiah 62. This paper has a purpose to introduce a textual criticism and a lexical analysis world to Old Testament students in Indonesia.

\section{"בניך" 62:5 THE TEXT OF ISAIAH}

\section{VARIANTS}

\section{A. BHS/Aleppo:}

Text:

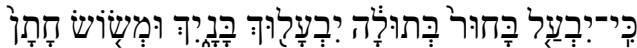

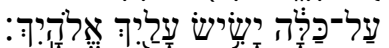

Translation:
For young man will marry with a virgin. Your sons will marry you and the rejoicing of bridegroom over the bride. So, your God will rejoice over you

Vorlage:

כי־יבעל בחור בתולה יבעלוך בניך ומשוש חתן על־כלה ישיש עליך אלהיך

\section{B. 1QIsa ${ }^{\mathrm{a}}$}

Text:

כי־יבעל בחור בתולה יבעלוכי בניך ומשוש ישל חתן על־כלה ישיש עליך אלהיך

Translation:

For young man will marry with a virgin. Your sons will marry you and the rejoicing of bridegroom over the bride. So, your God will rejoice over you

Vorlage: 


\section{כי־יבעל בחור בתולה יבעלוכי בניך ומשוש ישלי חתן על־כלה ישיש עליך ומשושיך אלהיך \\ C. 1QIsab}

Text:

כי־יבעל בחור בתולה יבעלוך בניך ומשוש חתן על־כלה ישיש עליך אלהיך

Translation:

For young man will marry with a virgin. Your sons / your builders will marry you and the rejoicing of bridegroom over the bride. So, your God will rejoice over you Vorlage:

כי-יבעל בחור בתולה יבעלוך בניך ומשוש חתן על־כלה ישיש עליך אלהיך

\section{Aquila:}

Text:

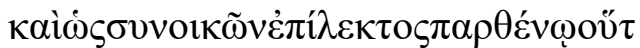


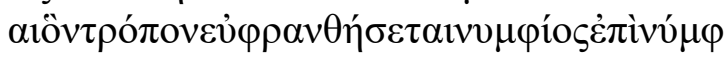

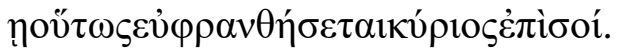

Translation:

And as a chosen one (picked) lives with a virgin, so shall thy sons dwell in thee; and it shall come to pass that as a bridegroom will rejoice over a bride; so, the Lord will rejoice over thee. ${ }^{1}$

Vorlage:

כי־יבעל בחיר בתולה יבעלוך בניך ומשוש חתן על־כלה ישיש עליך אלהיך

\section{E. Septuagint:}

Text:

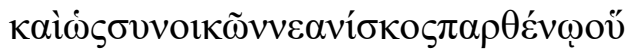
$\tau \omega \varsigma \kappa \alpha \tau$ เ

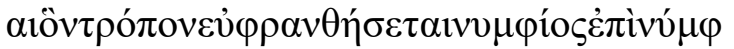

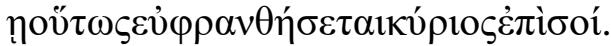

Translation:

And as a young man lives with a virgin, so shall thy sons dwell in thee; and it shall come to pass that as a bridegroom will rejoice over a bride; so, the Lord will rejoice over thee

Vorlage:

כי־יבעל בחור בתולה יבעלוך בניך ומשוש עליר חתן על־כלה ישיש עליך אלהיך

\section{F. Syriac:}

Text:

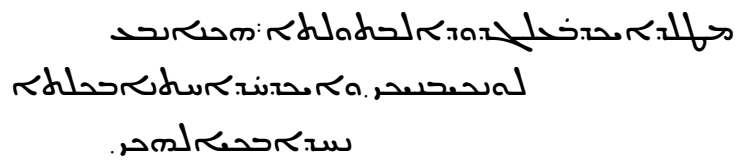

Translation:

For as a youth virgin, thus will your sons marry you and as the bridegroom rejoices in the bride, your God will rejoice in you.

Vorlage:

כי־יבעל בחור בתולה יבעלוך בניך ומשוש ישליכליכלי חתן על־כלה ישיש עליך אלהיך

\section{G. Targum:}

Text:

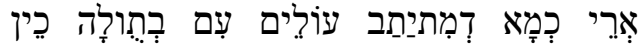

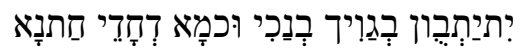

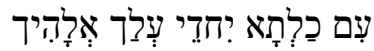

Translation:

For just as a young man cohabits with a virgin, so shall your sons co-inhabit in your midst, and just as the bridegroom rejoices with the bride, so shall your God rejoice over you.

Vorlage:

כי־יבעל בחור בתולה יבעלוך בניך ומשוש חתן על־כלה ישיש עליך אלהיך

\section{H. Vulgate:}

Text:

Habitabitenimiuvenis cum virgine et habitabunt in tefiliitui et gaudebitsponsus super sponsamgaudebit super te Deus tuus. Translation:

For as a young man marrieth a virgin, so shall thy sons marry thee: and as the bridegroom rejoiceth over the bride, thy God shall rejoice over thee.

Vorlage:

כי־יבעל בחור בתולה יבעלוך בניך ומשוש ישליר חתן על־כלה ישיש עליך אלהיך

\footnotetext{
בחור instead of בחיר Aquila seems employ
} 


\section{Arabic:}

Text:

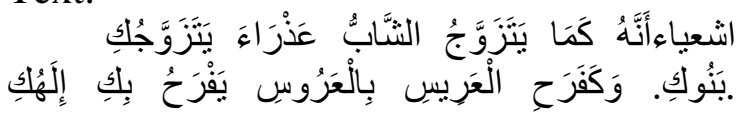

Translation: As a young man marries a maiden, so will your sons marry you; as a bridegroom rejoices over his bride, so will your God rejoice over you.

Vorlage:

כי־יבעל בחור בתולה יבעלוך בניך ומשוש חתן על- כליר כלה ישיש עליך אלהיך בחור על על יבור

The variants display two distinct problems. Nonetheless, this paper will analyze word problem of בניך

\section{PROBLEM: בניך}

\section{A. POSSIBLE READINGS}

\begin{tabular}{|l|l|l|l|}
\hline $\begin{array}{l}\text { (1) בניך) בניך (2) בניך (בניך) } \\
\text { (From the } \\
\text { noun }\end{array}$ & $\begin{array}{l}\text { (2) בנה } \\
\text { (From the } \\
\text { verb }\end{array}$ & & \\
\hline
\end{tabular}

\section{B. External Evidence}

\begin{tabular}{|c|c|c|c|c|}
\hline & $\begin{array}{l}\text { (1) בניד } \\
\text { (From the } \\
\text { noun } ן \text { ) }\end{array}$ & 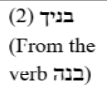 & בניד (3) & בנד (4) \\
\hline \multirow[t]{2}{*}{$\begin{array}{l}\text { Textual } \\
\text { Witnesses }\end{array}$} & MT & & \multirow[t]{2}{*}{$\begin{array}{l}\text { 1QIsa and } \\
1 \mathrm{QIsa}^{\mathrm{a}}\end{array}$} & \\
\hline & $\begin{array}{l}1 \mathrm{QIsa} \mathrm{Ia}^{\mathrm{a}} \mathrm{1Q \textrm {Q }} \\
\text { read to support } \\
\text { (2). }\end{array}$ & $\begin{array}{l}a^{b} \text { could be } \\
\text { ither (1) or }\end{array}$ & & \\
\hline $\begin{array}{l}\text { Translational } \\
\text { Witnesses }\end{array}$ & $\begin{array}{l}\text { LXX, Aquila, } \\
\text { Syriac, } \\
\text { Targum, } \\
\text { Arabic, } \\
\text { Vulgate }\end{array}$ & & & \\
\hline
\end{tabular}

Reading 4 is the weakest attestation and should be rejected based on the external evidence. Three of four first readings concur in their consonantal text, but the main problem is its root. It shows a propensity of highly interpretive translation its Vorlage is difficult to determine, although the table above favors the first reading.

\section{Internal Evidence}

\section{Simplification of the Text}

The difference between Readings 1 and 2

${ }^{2}$ In qal participle masculine plural construct with suffix $2^{\text {nd }}$ person feminine singular isderived from their vowels letter. The first reading choseqames-qames as its first two vowels פרני.: On the other hand, the second reading hadholem-patah as its first two vowels 2 . Therefore, the translation of first reading is "so shall your sons marry you", while the second is "your builders will marry you". Reading 4 can be translated as your builder as well.

The reason of this emendation is because the first reading seems unacceptable. The idea (concept) of incest which sons are marrying their mother is infelicitous. Therefore, BHS offers also the second reading that proposes to correct the

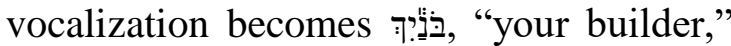
as referring to God (as in Ps. 147:2). It means that some translators have a predilection to adopt Reading 4.

\section{Explanatory Power}

Reading 1 and 2 have the same consonantal text but they are different in their vocalization. The second reading uses a verbal form and refers to the plural participle form, whereas the first reading employs a noun form. On the other hand, reading 4 denotes a singular noun because of the removal of '.

\section{Summary of Internal Evidence}

Reading 2 and 4 can be rejected for two reasons. First is the occurrence of this word in Hebrew Bible. The word ב ב w with the translation of your builders only occurs once in the Hebrew Bible (Ez. 27:4), ${ }^{2}$ while 44 times this word appears as your sons. In the book of Isaiah itself, the word seven times $(49: 17,22,25 ; 51: 20 ; 54: 13$;

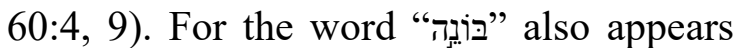
only once in the Old Testament with form qal participle masculine singular construct. ${ }^{3}$ The second reason is a contextual argument. The promise of descendants resonates in Isaiah 60-62 (60:4，9，21-22). These

${ }^{3}$ Four times this word emerges in the OT with form qal participle masculine singular absolute. 
descendants will work the land and profit from it as it is described in Isaiah 62:9. Prophesying that "your sons will marry you" indicates that the children of those who received the promise of the land will take possession of it while also accepting the responsibility to husband with joy akin to that of a new bridegroom.

\section{Conclusion}

Reading one has a stronger possibility of translation. The textual external evidence strongly favors the consonantal text of reading one because all the ancient versions support it. The internal evidence, though it is not as strong as external evidence, has endorsements from its context and appearances of that word in Hebrew Bible.

\section{LEXICAL STUDY OF İִּ IN ISAIAH 62:1}

\section{Usage in the MT}

The noun Hebrew Scriptures and only once occurs in the book of Isaiah. ${ }^{4}$ It is evenly divided between literal and symbolic meaning. A brief of its usage as classified by meaning is given below based on their various contexts.

\section{A. Summary of Usage. ${ }^{5}$}

1. Literal meaning:

a. Torch (Ju. 7:16; 7:20; 15:4; 15:4; 15:5).

b. Flaming Torch: usually with w (Gen. 15:17).

c. Lightning flashes (Ex. 20:18).

2. Symbolic meaning:

a. Symbolic of conquering power that Yahweh gives to Judah (Zech. 12:6).

b. Symbolic of the majestic the eyes of

${ }^{4}$ The controversial verse is Job 12:5. The first word, לִ (lapid), could be rendered "a torch of scorn". However, the $>$ (lamed) is often taken as an otiose letter, and the noun (pid) is "misfortune, angel (Dan. 10:6).

c. Symbolic of the furious and energetic action of war chariots to attack enemy (Na. 2:4).

d. Symbolic of the image of animal that of pent-up breath with water in a hot steam jet coming from its mouth.

e. Symbolic of the appearance of heavenly beings (Ez. 1:13).

f. Symbolic of Zion's glorious deliverance (Isa. 62:1).

\section{B. Observations}

From the literal meaning, the noun? gives out the light such as torch or flash. Hebrew Bible sometimes adds the word w to denote a flaming or burning connotation. However, in symbolic sense, the meaning should be scrutinized from the context. Nahum 2:4, for instance, uses לִִּּיד to symbolize the furious and energetic attack, but Ezekiel 1:13 depicts the magnificent of heavenly being appearance.

\section{Conclusion}

Based on this short study, the word לבפיד has both literal and symbolic which is depended to its context.

\section{Usage in Ancient Translations}

Employing ancient translations of Hebrew, such as Septuagint, we can obtain possible synonyms for our word of study synonyms, although sometimes generating previously unseen meaning, are most often helpful for depth studying to give diverse meanings which are a related to לִפִּ

\section{A. Septuagint}

In Septuagint, the text is $\delta i \grave{\alpha} \Sigma 1 \omega v o v ̉ \sigma i \omega \pi \eta ́ \sigma o \mu \alpha \iota \kappa \alpha i ̀ \delta ı ̀ ̀ I \varepsilon \rho o v \sigma \alpha \lambda \eta \mu o$

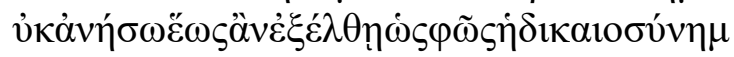

calamity" (cf. Job 30:24; 31:29). If this verse is counted, then it will be 14 verses.

${ }^{5}$ All of these verse follow NAS. 


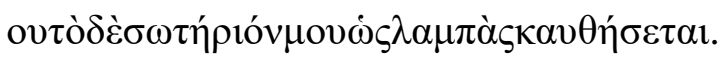

A Greek-English Lexicon of Septuagint gives other definitions regarding to this term: ${ }^{6}$

1. Something that gives out light: Torch

(Gen. 15:17; Na. 2:5; Zech. 12:6).

2. Flash(es) of lighting (Ex. 20:18).

\section{B. List of Synonyms}

Possible synonyms of לִִּּיד are listed below along with their basic definition.

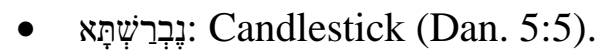

\section{Observation}

לִפִּ has one synonym which is

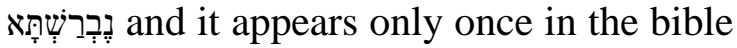

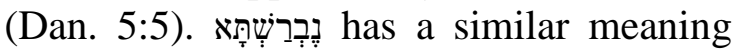
with the literal meaning of לִפּפיד

\section{Conclusion}

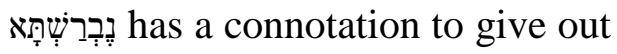
light as well as לִִּיד

\section{Cognate Languages}

By scrutinizing those languages which are connected to Hebrew, it is possible to find the history of the root לִיר? will assist to comprehend on the meanings presented above. The following cognates derive from BDB and HALOT. ${ }^{7}$

\section{A. List of Cognates}

- Jewish Aramaic: Shining object or torch.

- Syriac: Shining object or torch.

- Christian Palestinian Aramaic: Shining object or torch.

- Mandaean: Shining object or torch.

- Arabic: Shining object or torch.

\section{B. Observations:}

There is a united meaning throughout this list of cognates. All of them have shining object or torch definition.

\footnotetext{
${ }^{6}$ T. Muraoka, A Greek-English Lexicon of the Septuagint(Leuven, Belgium: PEETERS, Warotstraat, 2009), 424-5.

${ }^{7}$ Francis Brown, S. R. Driver, and C. A. Briggs, A

Hebrew and English Lexicon of the Old Testament
}

\section{Conclusion:}

Study of cognate languages is confirming the meaning of shining object or torch.

\section{Summary}

The general sense of לִ scrutinized in Biblical Hebrew usage, that it has dual meanings both literal and symbolic definition. Nevertheless, ancient translation and cognate languages denote the meaning of לברפיד only in literal sense. Hebrew Bible, on the other hand, shows the flexibility

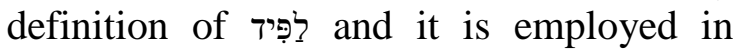
sundry contexts as symbolization.

In Isaiah 62:1, the best understanding of is not from literal sense but rather symbolic. The context of the usage of this term is God will restore Zion, particularly in her salvation, which is symbolized as a torch that burns. It means that Yahweh will make glorious Zion's deliverance like a torch so that all nations, including their kings, will be witnesses of Zion's restoration.

\section{REFERENCES}

[1] Ackerman, Susan. 'Sacred Sex, Sacrifice and Death: Understanding a Prophetic Poem',

Bible Review 6 (Feb. 1990).

[2] Andersen, F. I. 'Salience, Implicature, Ambiguity and Redundancy in clauseclause

relationships in Biblical Hebrew'. InBiblical Hebrew and Discourse linguistics,

ed. R.D Bergen. Winona Lake, IN: Eisenbrauns, 1994.

[3] Blenkinsopp, Joseph. Isaiah 56-66 A New Translation with Introduction and Commentary. New York: The Anchor Bible, 2003.

(Oxford: Clarendon Press); and Ludwig Koehler and Water Baumgartner, The Hebrew and Aramaic Lexicon of Old Testament, 5 Vols. (New York: E. J Brill, 1994). 
[4] Brown, Francis S. R. Driver, and C. A. Briggs, AHebrew and English Lexicon of the Old

Testament Oxford: Clarendon Press, 1994. [5] Brueggemann, Walter. Isaiah 40-66. Louisville, Kentucky: Westminster John Know

Press, 1998.

[6] Buksbazen, Victor. The Prophet Isaiah. Collingswood, N.J: The Spearhead Press, 1971.

[7] Butler, Paul T. Isaiah III. USA: College Press Publishing Company, 1978.

[8] Davies, Andrew. Double Standards in Isaiah Re-evaluating Prophetic Ethics \& Divine

Justice. Netherlands, Leiden: Koninklijke Brill, 2000.

[9] Goldingay, John. New International Biblical Commentaryon Isaiah. Peabody,

Massachusetts: Hendrickson Publishers, Inc. 2001.

[10] Horton, Stanley M. Isaiah. Springfield, Missouri: Gospel Publishing House, 2000.

[11] Koehler, Ludwig and Water Baumgartner, The Hebrew and Aramaic Lexicon of Old

Testament, 5 Vols. New York: E. J Brill, 1994.

[12] Mackay, John L. Isaiah 4066.Faverdale North, Darlington: MPG Books Group, 2009.

[13] T. Muraoka, A Greek-English Lexicon of the Septuagint. Leuven, Belgium: PEETERS,

Warotstraat, 2009.

[14] Oswalt, John N. The Book of IsaiahChapter 1-39. Grand Rapids, Michigan: William B.

Eerdmans Publishing Company, 1986.

[15] , The book of Isaiah.

Chapter 40-66. Grand Rapids, Michigan: Wm. B.

Eerdmans Publishing Co., 1998.

[16] Schullion, SJ, John. Old Testament Message: A Biblical-Theological Commentary on

Isaiah 40:66. Wilmington, Delaware: Michael Glazier, Inc, 1982.
[17] Smart, J. D. History and Theology in Second Isaiah. Philadelphia: Epworth, 1965.

[18] Thompson, Michael. Isaiah 40-66.Ivatt Way, Peterborough: 2001.

[19] Westermann, Claus. Isaiah 40-66. Westminster: John Knox Press, 1969.

[20] Whybray, R. N. Isaiah 40-66. Grand Rapids, Michigan: WM. B. Eerdmans Publ. Co.,

1975.

[21] Williams, Ronald J. Williams' Hebrew Syntax. Canada: University of Toronto, 2007.

[22] Young, Edward J. The book of Isaiah 40-66. Grand Rapids, Michigan: William B. Eerdmans Publishing Company, 1972. 